\title{
In Memoriam: Professor Beloslav Riečan
}

\section{Katarína Čunderlíková}

\author{
Mathematical Institute, Slovak Academy of Sciences \\ Štefánikova 49, 81473 Bratislava, Slovakia \\ e-mail: cunderlikova.lendelova@gmail.com
}

On August 13, 2018, Matej Bel University Professor Emeritus Beloslav Riečan, and member of the Editorial Board of Int. J. Notes on Intuitionistic Fuzzy Sets, passed away at the age of 81. He belongs to the pleiades of the most important mathematicians of Slovakia.

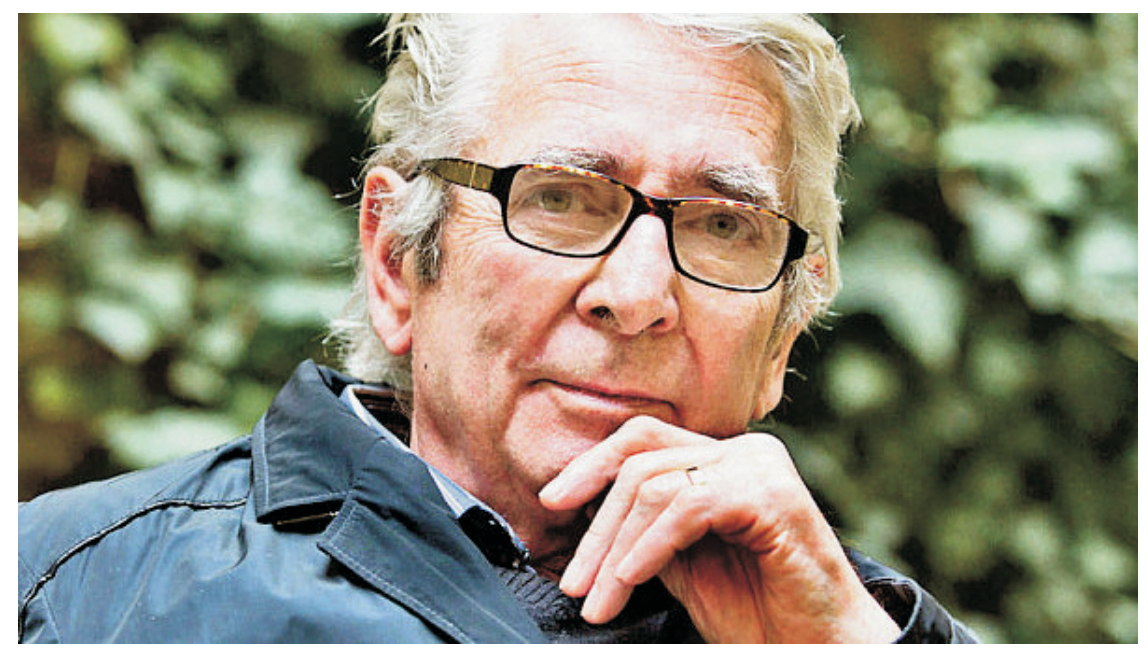

Prof. B. Riečan was born on November 11, 1936 in Žilina. After the mother's death, the family moved to Banská Bystrica. Here he attended the primary school and a very famous high school, Gymnázium of Andrej Sládkovič. In years 1953-1958 he studied at Faculty of Natural Science of Comenius University in Bratislava, discipline Mathematics, specialization Mathematical Analysis. Here he had excellent teachers who belong to the first generation of the Slovak Mathematicians: Jur Hronec, Otakar Borůvka, Michal Greguš, Anton Hǔ̆a, Milan Kolibiar, Tibor Neubrunn, Tibor Šalát and Valter Šeda. His school-class was one of the best in the history; his student fellows became a decoration of the Slovak mathematical Society: Pavol Brunovský, Ján Černý, Arnold Dávid, Jozef Gruska, Pavol Kluvánek, Zdena Petrovičová-Riečanová, Jozef Moravčík, Miloš Franek, Zoltán Zalabai and others. During his studies he writed to scientific 
activity under guidance of Prof. Milan Kolibiar and immediately his first paper On axiomatic of modular lattices, Acta Fac. Rer. Nat. Univ. Comenianae, Math. 2 (1957), 257-262 (in Slovak), was a top hit. This paper was quoted in monographs of G. Birghoff, L. A. Skornjakov and G. Grätzer. Every specialist of lattice theory knows very well how a great distinction for the author are such quotations in these three fundamental books.

After finishing his studies in 1958, he started to work at the Department of Mathematics of the Slovak Technical University, Bratislava (1958-1971). In 1962-1964 he was a PhD-student of Prof. Štefan Schwarz, another giant of the Slovak Maths. In 1965 he defended the PhD-thesis On some relations between measure and topology at the Mathematical Institute of Slovak Academy of Sciences in Bratislava. In 1966 he was the Associated Prof., and he started to give lectures also at Faculty of Natural Sciences of Comenius University. In 1980 he defended the scientific degree DrSc. by work On two conceptions of measure theory, and in 1981 he was appointed as the University Professor. From 1972 he worked at this Faculty, and in 1985 he moved to Liptovský Mikuláš, to the Department of Math. of the Military Academy to come back in 1989 to Faculty of Mathematics and Physics, Bratislava, as the first willingly elected Dean. Since 1992 he was the Director of Institute of Mathematics of the Slovak Academy of Sciences, and since 1998 he is back in the city of his youth, Banská Bystrica, where he was the Professor at the Department of Mathematics, Faculty of Natural Sciences of the Matej Bel University.

Prof. Riečan belongs to the pleiades of the most important mathematicians of Slovakia. He is the author or coauthor of 7 monographs, 300 papers published in scientific journals, 80 technical papers, 5 university textbooks, 71 high-school textbooks and text tools, 9 scripts, 11 books on mathematics, $8 \mathrm{tv}$-scripts, over 400 publicists articles. His papers were quoted in more than 500 articles. He was a PhD-supervisor of $34 \mathrm{PhD}$-students, which is a Slovak unique, and he was a supervisor of over 55 diploma-theses. Many of his former students are nowadays leading personalities of our universities and of the Slovak Academy of Sciences. His professional activity was probability theory, measure theory and integration, fuzzy sets, intuitionistic fuzzy sets and quantum structures.

His scientific, pedagogical, organizing activity was many time awarded on many national and international platforms. I mention only the latest ones: Honorary member of Union of Slovak Mathematicians and Physicists (1987), the Gold Honourable Plague of Jur Hronec of the Slovak Academy of Sciences in Bratislava for deserts in the Mathematical Sciences (1995), the Gold Medal of the Faculty of Mathematics and Physics, Comenius University in Bratislava (1996), Honourable Medal of Bernard Bolzano of the Academy of Sciences of the Czech republic (1998), the Silver Medal of University of Milano (2000), the Medal of the Slovak Academy of Sciences for support for science (2001), the Decoration of Ľudovít Štúr first-rate (2002), the Commemorative medal of Faculty of Mathematics and Physics Carolinium University in Prague (2004), Dr.h.c of Academy M.R. Štefánik in Liptovský Miluláš (2006), the Mathematical Medal of Union Czech Mathematicians and Physicists (2008), the Gold Medal of Constantine the Philosopher in Nitra (2010), Dr.h.c. of Carolinium University in Prague (2012) and others. He was a member of the editorial boards of many mathematical and cultural journals.

Prof. Riečan was a fanatic propagator of mathematics and music, too. As an outstanding musician and musical expert, since 1984 together with an important Slovak musician Prof. Roman 
Berger are guiding the Seminar Mathematics and Music, and around this seminar a circle of Slovak, Czech as well as foreigner intellectuals is concerned.

He can be considered the father of fuzzy sets and intuitionistic fuzzy sets in Slovakia. The beginnings of his interest in unusual modeling of uncertainty can be found in collaboration with Prof. Tibor Neubrunn. With him he wrote a monograph Miera a integrál in 1981. Later it was published as an English translation supplemented with the theory of fuzzy sets under name Integral, Measure and Ordering in 1997. He further cooperated with Czech colleagues like Prof. Vilém Novák who discovered fuzzy sets soon after their introduction by Prof. L. Zadeh in 1965. In 1986, he published the first article of the Slovak author in the field of fuzzy sets, namely the paper On a fuzzy approach to some problems of measure theory in the journal BUSEFAL. In addition to the creation of the School of fuzzy quantum structures (1988), leading to the introduction of D-posets by F. Kôpka and F. Chovanec, we can not forget to his introduction of product MV-algebras in the International Journal of Theoretical Physics in 2000. A good overview of the results in this structure can be found in the chapter Probability on MV-algebras of the book Handbook of Measure Theory (E. Pap editor), written together with D. Mundici in 2002. A major influence on many of his students and co-workers had his article A descriptive definition of probability on intuitionistic fuzzy sets published in the EUSFLAT 2003 Proceedings. He introduced a research of the intuitionistic fuzzy sets in Slovakia by this paper. The intuitionistic fuzzy sets were founded by K.T. Atanassov in 1989. In this area, cooperation with many Polish mathematicians (Przemyslaw Grzegorzewski, Eulalia Szmidt, Janusz Kacprzyk and others) and Bulgarian mathematicians (K.T. Atanassov, Vassia Atanassova, Lyubka Doukovska and others) began. He and his collaborators have brought new results in the field of the intuitionistic fuzzy probability theory, the intuitionistic fuzzy measure theory and the intuitionistic fuzzy dynamical systems. Thanks to Prof. Beloslav Riečan, Banská Bystrica became the center of research the intuitionistic fuzzy sets in Slovakia last ten years.

Dear Belo, thank you for your fatherly approach, for your good advice as a teacher and for your friendship. We will continue with your work. Rest in peace!

Katarína Čunderlíková

\section{List of Riečan's PhD. students:}

1. Doc. RNDr. Rastislav Potocký, CSc. (1977)

2. RNDr. Eugen Futáš, CSc. (1977)

3. Doc. RNDr. Michal Šabo, CSc. (1978)

4. Doc. RNDr. Jozef Kalas, CSc. (1978)

5. Doc. RNDr. Peter Volauf, CSc. (1979)

6. Prof. RNDr. Madga Komorníková, CSc. (1979)

7. Prof. RNDr. Radko Mesiar, DrSc. (1979)

8. Doc. RNDr. Peter Vrábel, CSc. (1981)

9. Doc. RNDr. Stanislav Palúch, CSc. (1983)

10. RNDr. Pavol Černek, CSc. (1983)

11. Doc. RNDr. Ing. Blahoslav Harman, CSc. (1983)

12. Doc. RNDr. Marta Vrábelová, CSc. (1984) 
13. RNDr. Oľga Kulcsárová, CSc. (1984)

14. Doc. RNDr. Peter Maličký, CSc. (1985)

15. RNDr. Ervin Hrachovina, CSc. (1986)

16. RNDr. Ján Bán, CSc. (1989)

17. Prof. RNDr. Dagmar Markechová. CSc. (1990)

18. Doc. RNDr. František Kôpka, CSc. (1991)

19. Doc. RNDr. Mária Jurečková, CSc. (1992)

20. RNDr. Adrián Kacian, PhD. (2000)

21. RNDr. Jozefína Petrovičová, PhD. (2000)

22. RNDr. Katarína Čunderlíková (Lendelová), PhD. (2006)

23. RNDr. Alžbeta Michalíková, PhD. (2007)

24. RNDr. Petra Mazureková, PhD. (2009)

25. RNDr. Magdaléna Renčová, PhD. (2009)

26. RNDr. Marek Ďurica, PhD. (2009)

27. RNDr. Lenka Mackovičová (Lašová), PhD. (2010)

28. RNDr. Veronika Bojdová (Valenčáková), PhD. (2010)

29. Mgr. Ivana Hollá, PhD. (2011)

30. RNDr. Karol Samuelčík, PhD. (2011)

31. Mgr. Mária Kuková, PhD. (2012)

32. Ing. Jana Kelemenová, PhD. (2012)

33. Mgr. Daniela Kluvancová, PhD. (2017)

34. Mgr. Jaroslav Považan, PhD. (2017)

List of Riečan's students, who wrote his first scientific work under his direction:

1. Doc. RNDr. Ján Šipoš, CSc.,

2. Doc. RNDr. František Rublík, CSc.,

3. Prof. RNDr. Anatolij Dvurečenskij, DrSc. (supervisor-specialist),

4. Prof. RNDr. Jozef Komorník, DrSc.,

5. Doc. RNDr. Martin Kalina, CSc.,

6. Doc. RNDr. Ferdinand Chovanec, CSc.,

7. Prof. RNDr. Otokar Grošek, CSc.,

8. Doc. RNDr. Viktor Witkovský, DrSc.,

9. Doc. RNDr. Ivan Mizera, CSc.,

10. Doc. RNDr. Oleg Palumbíny, CSc.

\section{References}

[1] Čunderlíková, K. (2018) A memory of Prof. RNDr. Beloslav Riečan, DrSc. Journal of Universal Mathematics, 1(3), 258-260.

[2] Lendelová, K. (2006) Prof. RNDr. Beloslav Riečan, DrSc. septuagenarian. Notes on Intuitionistic Fuzzy Sets, 12(4), 1-2.

[3] Kovačka, M., et al. (2013) Beloslav Riečan. Alfa print s.r.o., Martin. 